\title{
Phenotypical correlations between agronomical characters in Prata type bananas (Musa) and its implications on yield estimate
}

\author{
Bruno Vinícius Castro Guimarães ${ }^{1 *}$, Sérgio Luiz Rodrigues Donato ${ }^{2}$, Victor Martins Maia ${ }^{3}$, \\ Ignacio Aspiazú ${ }^{3}$ and Eugênio Ferreira Coelho ${ }^{4}$
}

${ }^{1}$ Instituto Federal do Amazonas Campus São Gabriel da Cachoeira, Rodovia BR 307, Km 03, s/no, Estrada do Aeroporto, Cachoeirinha, CEP 69750-000, São Gabriel da Cachoeira, AM.

${ }^{2}$ Instituto Federal Baiano Campus Guanambi, Caixa Postal 09, Distrito de Ceraima, CEP 46430-000, Guanambi, BA.

${ }^{3}$ Universidade Estadual de Montes Claros, Rua Reinaldo Viana, 2630, Bico da Pedra, CEP 39440-000, Janaúba, MG.

${ }^{4}$ Embrapa Mandioca e Fruticultura, Caixa Postal 007, Rua Embrapa, s/n, CEP 44380-000, Cruz das Almas, BA.

Received 12 November, 2012; Accepted 24 March, 2014

\begin{abstract}
This research aims to estimate correlations between agronomic traits and yield in Pome bananas, contributing to the elaboration of models for estimation of harvest. Agronomic traits were evaluated in 98 plants of 'Dwarf Prata' and 96 'BRS Platina', considered replicates and sampled at random. Correlations between the masses of the bunch, and hands and plant height; pseudostem perimeter at ground level, at $30 \mathrm{~cm}$ and at $100 \mathrm{~cm}$ in height; number of green leaves; mass of the bunch; number of hands and fruits per bunch; mass of the hands; mass, length and diameter of the stem, and mass of the fruit of the external row from the first to the tenth hand were estimated. The highest correlation coefficient between yield and vegetative traits for 'Dwarf Prata' and 'BRS Platina', was obtained for pseudostem perimeter at ground level, indicating its greater potential to compose harvest estimation models. The correlations between the masses of the bunch and hands with yield traits, for both genotypes, showed a higher potential for predicting the number of hands and fruits. Appropriate correlation estimates are associated with the fourth and fifth bunch, for the 'Dwarf Prata' and 'BRS Platina', respectively, using the mass of the fruit of the external row.
\end{abstract}

Key words: Banana, phenotypical descriptors, statistics, associations, genotypes.

\section{INTRODUCTION}

The banana crop (Musa) has a social and economical importance in over 80 countries, especially in small properties (Silva et al., 2002). Brazil is the fifth main banana producer in the world, with 6.9 thousand tons produced in 481 thousand hectares, resulting in anaverage yield of 14.3 ton $\mathrm{ha}^{-1}$ (FAO, 2013).

Among the most planted cultivars nationwide, the Prata, Dwarf-Prata, Pacovan and Common-Prata types can be highlighted, since they represent almost $80 \%$ of the area cultivated with bananas (Silva et al., 2008). 
Despite the importance of these genotypes, all of them are susceptible to the main bananas pests and diseases, and, in the last years, the Panama disease has become a serious problem. It is causing limitations in important producing areas of the country, especially in some properties with sandier soils (Rodrigues et al., 2011).

In the light of these facts, it becomes evident the importance of developing breeding programs aiming to obtain cultivars with adequate height, adapted to different ecosystems, and resistant to the main diseases and pests, as well as improving fruit quality (Donato et al., 2006a), in order to supply the increasingly demanding consumer and producer markets..

According to Vencovsky and Barriga (1992), this kind of studies provide important information for genetic breeding, such as the possibility of identifying the proportion of phenotypic correlation that occurs due to genetic causes; verify if the selection in one character affects the other; quantify indirect increases due to selection made in correlated characters; and evaluate the complexity of the characters. Knowledge about the association between characters is very important, especially if the selection of one of them is difficult, due to low heritability or difficult measuring and identification problems.stimates of phenotypical correlations involving production bananas, yield components and other important characters in bananas can be found in several articles (Arantes et al., 2010; Donato et al., 2006a; Lima Neto et al., 2003; Soares et al., 2012; Tenkouano et al., 2002). However, for same character, it can be identified the estimate of positive, negative or null values. This can be explained by the fact that those correlations were estimated in different genotypes and environments, using different methods. Hence, if there is a possibility, new correlations should be estimated to help the conduction of a breeding program (Vencovsky and Barriga, 1992). Still, a correlation study can be employed to predict values related to harvest using significant variables that associate highly with production.

Therefore, it is important to identify variables associated with high productivity for use in mathematical modeling to estimate the harvest, based on agronomic traits measured during the crop cycle. In this case, the mathematical model, provided that it is adjusted in a functional way, allows those involved with the bananas crop, whether a researcher and/or a producer, planning and organization of pre- and post-harvest operations. Still, it is noteworthy that the regression models generated a posteriori may indicate the need for subsequent management adjustments to enable correction of characteristics that show unfavorable at any given time, especially for the next crop cycle.

Thus, the analysis of behavior and expression of the plants is of wide interest to those engaged in plant production research, being very useful for proper planning of agricultural activities. This way, several statistical studies, linear and nonlinear, are developed with the purpose of obtaining information and describe future plant growth over time (Hernández et al., 2007; Maia et al., 2009; Scarpari and Beauclair, 2009; Soares et al., 2012), from the analyses of the correlation coefficients among the plant variables.

As an outcome of the above, this work was carried out with the objective of estimating the correlations between agronomic characters and yield in type Prata bananas, so that it can contribute to the elaboration of models to estimate harvest.

\section{MATERIALS AND METHODS}

The experiment was established in a Red-Yellow Latosol (Hapludox), medium texture, hypoxerophilous Caatinga (thornshrub savannah) phase, with flat to moderate topography. The area is located at the Instituto Federal Baiano, in the Guanambi Campus, $\mathrm{BA}, 14^{\circ} 13^{\prime} 30$ "S, $42^{\circ} 46^{\prime} 53^{\prime \prime} \mathrm{W}, 545 \mathrm{~m}$ of altitude, average annual precipitation of $663.69 \mathrm{~mm}$, average temperature of $26^{\circ} \mathrm{C}$ and relative humidity of $64 \%$. The local climate is Aw, according to Köppen's classification.

Micropropagated bananasplantlets were used, in a $3.0 \times 2.5 \mathrm{~m}$ spacing and irrigated with fixed micro-sprinklers. Installation and cultivation followed the recommendations for the crop, and fertilizers were applied based on analysis of soil and leaves. The two evaluated genotypes were: Dwarf Prata, triploid (AAB), susceptible to yellow and black Sigatoka and Panama disease; and the BRS Platina hybrid, tetraploid (AAAB), resistant to yellow Sigatoka and Panama disease, derived from the cross between 'Dwarf Prata' (AAB) and M53 diploid (AA), formerly known in prerelease as PA42-44.

Measurements were made at the time of harvest. Each plant, the basic unit, was considered as a replicate. Therefore, to assess vegetative and yield characteristics, the plants were sampled at random into the two genotypes with different numbers of replicates, 98 for 'Dwarf Prata' and 96 for 'BRS Platina'.

The measurements consisted of phenotypic vegetative descriptors plant height, pseudostem perimeter at ground level, 30 and $100 \mathrm{~cm}$ in height, number of green leaves at harvest. Bunch yield characteristics bunch weight, number of hands and fruits per bunch, hands mass and stem mass, length and diameter were determined, as well as hands yield characteristics number of total fruits and fruits per bunch, and mass, internal and external length and diameter of the central fruit on the external and internal rows were determined. The measured values were obtained according to the methodological proposal contained in catalogs of standard morphological descriptors for bananas (Descriptors for banana, 1996).

For each evaluated genotype, 'Dwarf Prata' and 'BRS Platina', phenotypic correlations were estimated from the associations between the masses of the bunch and hands with the evaluated yield and vegetative characteristics, based on Pearson correlation (Steel et al., 1997). The data came from observations of individual replicates of each genotype for establishing associations between characteristics.

\section{RESULTS AND DISCUSSION}

In order to characterize the 'Dwarf Prata' and 'BRS Platina' bananas, Tables 1 and 2 show the averages and standard deviations of the evaluated vegetative and yield characteristics. Those allowed the correlation statistical procedure and implications in harvest estimates. 
Table 1. Averages and standard deviations of the vegetative characteristics of 'Dwarf Prata' and 'BRS Platina' bananas.

\begin{tabular}{lccccc}
\hline Genotypes & ${ }^{\mathbf{1}} \mathbf{P H}(\mathbf{c m})$ & ${ }^{\mathbf{2}}$ PPGL (cm) & ${ }^{3}$ PP30 (cm) & ${ }^{4}$ PP100 (cm) & ${ }^{\mathbf{5}}$ NGH (un) \\
\hline Dwarf Prata & $335 \pm 35$ & $113 \pm 14$ & $99 \pm 14$ & $78 \pm 9$ & $14 \pm 2$ \\
BRS Platina & $348 \pm 34$ & $108 \pm 10$ & $93 \pm 9$ & $72 \pm 8$ & $11 \pm 2$ \\
\hline
\end{tabular}

${ }^{1} \mathrm{PH}$, Plant height; ${ }^{2} \mathrm{PPNS}$, pseudostem perimeter at ground level; ${ }^{3} \mathrm{PP} 30$, pseudostem perimeter at $30 \mathrm{~cm}$ height; ${ }^{4} \mathrm{PP} 100$, pseudostem perimeter at $100 \mathrm{~cm}$ height; ${ }^{5} \mathrm{NGH}$, number of green leaves at harvest time.

Table 2. Averages and standard deviations of the yield characteristics of 'Dwarf Prata' and 'BRS Platina' bananas.

\begin{tabular}{lcc}
\hline \multirow{2}{*}{ Characteristics } & \multicolumn{2}{c}{ Genótipos } \\
\cline { 2 - 3 } & Dwarf Prata & BRS Platina \\
\hline Bunch mass (kg) & $27 \pm 6$ & $24 \pm 5$ \\
Hands mass (kg) & $24 \pm 5$ & $21 \pm 5$ \\
Number of hands (un) & $11 \pm 1$ & $8 \pm 1$ \\
Average hands mass (kg) & $2.16 \pm 0.39$ & $2.58 \pm 0.50$ \\
Stem mass (kg) & $2.83 \pm 0.39$ & $2.55 \pm 0.55$ \\
Stem length (cm) & $38.61 \pm 8.94$ & $43.07 \pm 8.04$ \\
Stem diameter (mm) & $73.27 \pm 8.15$ & $68.51 \pm 6.68$ \\
Number of fruits (un) & $183 \pm 26$ & $128 \pm 21$ \\
\hline
\end{tabular}

The average values and the variability of yield and vegetative characteristics (Tables 1 and 2) measured in the bananas 'Dwarf Prata' and 'BRS Platina' are in agreement with data obtained in the same cultivation area for the same genotype (Donato et al., 2006, 2009).

Analyzing Table 1 , it is seen that the genotypes Dwarf Prata and BRS Platina present proximity of vegetative characteristics values. Several authors confirm the size similarity of the genotypes (Donato et al., 2006, 2009; Ledo et al., 2008; Oliveira et al., 2008; Marques et al., 2011). However, these studies observed the superiority of the progenitor compared to the hybrid, regarding the pseudostem perimeter and number of green leaves at harvest. However, Donato et al. (2009) found similarities between these genotypes also for these latter characteristics.

The 'Dwarf Prata' has larger values for the characteristics number of hands and fruits compared to the hybrid, while the 'BRS Platina' is more expressive for the value of the average weight of the bunches (Table 2). In this context, several studies confirm these differences between 'Dwarf Prata' and 'BRS Platina', which indicate that these are varietal differences that happen regardless of environmental and management conditions (Donato et al., 2006; Ledo et al., 2008; Donato et al., 2009; Marques et al., 2011). Thus, considering that bananas are commercialized upon classification, which includes fruit dimensions, both genotypes presented fruits that would be well ranked (Table 2), with an advantage for the 'BRS Platina'.
The correlations between the masses of the bunch and hands and the vegetative characteristics plant height, pseudostem perimeter at ground level, at 30 and $100 \mathrm{~cm}$ in height, and number of green leaves at harvest for the 'Dwarf Prata' and 'BRS Platina' bananas were significant and positive for all variables (Table 3 ). This indicates the direct variation of the yield variables masses of the bunch and hands with the vegetative variables analyzed in this work.

Thus, the genotypes 'Dwarf Prata' 'and 'BRS Platina' showed positive and significant correlations between the average bunch and hands masses with plant height. This association denotes the direct variation of these bunch and hands masses with the size of the plant. However, the magnitude of this correlation was the lowest among the vegetative variables evaluated for hybrid BRS Platina (Table 3). Soares (2013) stated the same for the cultivar tropical. However, Siqueira (1984) found, from clones of 'Prata' bananas, that it is possible to select smaller genotypes without production impairing, as plant height, in most of the evaluated clones, did not correlate with any yield-associated character.

From the analysis of the association between masses of bunch and hands and the pseudostem perimeter measured at ground level, at 30 and $100 \mathrm{~cm}$ from ground, satisfactory correlation estimates can be observed. However, the association with the pseudostem perimeter at ground level expressed better response, which suggests its use as an effective variable for prediction (Table 3). Despite being measured at harvest time, the 
Table 3. Correlation coefficients between the masses of the bunch and hands, with the vegetative characteristics of Prata type bananas, 'Dwarf Prata' and 'BRS Platina'.

\begin{tabular}{lcccc}
\hline \multirow{2}{*}{ Vegetative characteristics } & \multicolumn{2}{c}{ Genotypes } & \multicolumn{2}{c}{ Genotypes } \\
\cline { 2 - 5 } & \multicolumn{2}{c}{ Bunch mass } & \multicolumn{2}{c}{ Hands mass } \\
\cline { 2 - 5 } & Dwarf Prata & BRS Platina & Dwarf Prata & BRS Platina \\
\hline Plant height & $0.63^{\star \star}$ & $0.49^{\star \star}$ & $0.63^{\star \star}$ & $0.47^{\star \star}$ \\
Pseudostem perimeter at ground level & $0.75^{\star \star}$ & $0.75^{\star \star}$ & $0.75^{\star \star}$ & $0.73^{\star \star}$ \\
Pseudostem perimeter at $30 \mathrm{~cm}$ height & $0.69^{\star \star}$ & $0.64^{\star \star}$ & $0.68^{\star \star}$ & $0.63^{\star \star}$ \\
Pseudostem perimeter at $100 \mathrm{~cm}$ height & $0.68^{\star \star}$ & $0.74^{\star \star}$ & $0.67^{\star \star}$ & $0.72^{\star \star}$ \\
Number of green leaves at harvest time & $0.35^{\star \star}$ & $0.52^{\star \star}$ & $0.35^{\star \star}$ & $0.52^{\star \star}$ \\
\hline
\end{tabular}

**Significant at $1 \%$ level of significance.

pseudostem perimeter would present the same dimensions as if it were assessed at flowering, as this characteristic remains constant after that, since at this time, the bananas tree ceases the development of roots and leaves, beginning senescence of these organs and culminating with bunch ripening (Robinson and Galán Saúco, 2010). Additionally, to compose the prediction equations, the variables must be easily measurable and of simple practical implementation, allowing the determination in advance of the phenomenon to be predicted about 120 to 150 days before bananas harvest bananas (Donato et al., 2006, 2009).

Different studies correlating vegetative and reproductive characteristics in bananas report a significant correlation between pseudostem perimeter and bunch production (Lima Neto et al., 2003; Arantes et al., 2010). In addition, Siqueira (1984) found, from clones of 'Prata' bananas, that among the vegetative growth related characters, the pseudostem perimeter was the most positively correlated with the production characters.

However, this result does not agree with Donato (2006a) and Soares (2013), who state that bunch weight and pseudostem perimeter correlation is not significant and positive, which may indicate that, regardless of pseudostem thickness, the bunch mass may have a satisfactory value. However, genotypes with higher and lower height showed, respectively, higher and lower pseudostem perimeter as well. In addition, Lima Neto (2003) found that the correlation between bunch mass and pseudostem diameter in 'Gros Michel' bananas is not usually influenced by environmental factors.

In this work, the values found were statistically significant and positive for the association bunch and hands masses with the number of green leaves at harvest for 'Dwarf Prata' and 'BRS Platina' (Table 3). However, the highest correlation estimate was expressed by the hybrid, but for the two genotypes the correlation was low. This result can be attributed to the high number of leaves present at harvest time, with an average of 14 and 11 leaves, respectively, for genotypes Dwarf Prata and BRS Platina. Thus, the 'BRS Platina' had fewer leaves, but higher correlation coefficient (0.52) than the
'Dwarf Prata' (0.35), which had more leaves (Table 3). In a study conducted in northern Minas Gerais, the 'Dwarf Prata' bunches were heavier when the plant was maintained with a minimum of 12 leaves. Therefore, the amount of leaves recorded in this study meets the minimum requirement to normally fill banana bunches in 'Prata' type bananas (Rodrigues et al., 2009), which explains the low correlation. Additionally, the evaluation was done at harvest time, and not at flowering time, when it could be expected a higher correlation between these variables.

However, some authors do not share these same results, since those genotypes showed non-significant and positive values for the association number of leaves at harvest time and bunch yield, in both production cycles (Lima Neto et al., 2003; Donato et al., 2006a). Nevertheless, Siqueira (1984) noted significant correlations between the referred characters. According to the exposed by the correlations in this study and in others reviewed, it can be inferred that these characters do not show strong correlation, and that may cause low reliability for harvest prediction if used as a model component.

In this context, Soares (2013) observed that, despite being significant and positive, the relation bunch mass and number of green leaves showed a correlation coefficient of low magnitude. This indicates that the bunch mass varies in a direct way in relation to the number of green leaves, but, if the minimum demands of number of leaves is met, this influence is not expressive.

Correlations between bunch mass and other yield descriptors measured at the harvest time were positive and significant at a $1 \%$ level of probability, except for stem length in the genotype BRS Platina, which was nonsignificant (Table 4). This way, the bunch mass varied in the same way as the other yield characters considered. Nevertheless, in prediction studies, it is desirable that the variable that composes the model show high correlation coefficient and also easy measuring in the field.

The bunch mass in relation to the hands mass expressed the highest correlation, 0.99 for both genotypes, Dwarf Prata and BRS Platina, as expected, 
Table 4. Phenotypic correlation coefficients between bunch mass and other yield characteristics in Prata type bananas, 'Dwarf Prata' and 'BRS Platina'.

\begin{tabular}{lcc}
\hline \multirow{2}{*}{ Yield characteristics of the bunch } & \multicolumn{2}{c}{ Genotypes } \\
\cline { 2 - 3 } & Dwarf Prata & BRS Platina \\
\hline Hands mass & $0.99^{\star \star}$ & $0.99^{\star \star}$ \\
Stem mass & $0.82^{\star \star}$ & $0.71^{\star \star}$ \\
Stem length & $0.35^{\star \star}$ & $0.08^{\text {ns }}$ \\
Stem diameter & $0.69^{\star \star}$ & $0.68^{\star \star}$ \\
Number of hands & $0.70^{\star \star}$ & $0.60^{\star \star}$ \\
Number of fruits & $0.74^{\star \star}$ & $0.74^{\star \star}$ \\
Average hands mass & $0.86^{\star \star}$ & $0.89^{\star \star}$ \\
\hline
\end{tabular}

** and ${ }^{\text {ns }}$ : significant at $1 \%$ level of significance and non-significant, respectively.

because the hands mass is the main component of the bunch, only without the rachis (Table 4). The general behavior of this correlation is similar to that obtained by other authors (Jaramilo, 1982; Lima Neto et al., 2003; Donato et al., 2006a). However, although this is a high magnitude and significant association, it presents a limitation as a variable to be used in harvest prediction, since it assumes the condition of response variable, as well as the bunch mass.

The correlation between masses of bunch and stem, for the studied genotypes, showed statistically significant and positive values (Table 4). However, Donato et al. (2006a) found varied correlations for the approached genotypes, being significant and positive the correlation for 'Dwarf Prata'. However, for the BRS Platina hybrid, it was found a significant and negative correlation. Nevertheless, the variable stem mass, to estimate harvest, is considered as a destructive and hard to measure sample, because to quantify its mass, it is necessary to detach the whole bunch. These reasons, coupled with its measurement period, which coincides with the measurement period of the phenomenon that is intended to be predicted, make the variable of little practical application for harvest prediction.

The association between bunch mass and stem length, despite being significant and positive for 'Dwarf Prata', showed the lower estimate, 0.35 , and for 'BRS Platina', it was non-significant, with a value of 0.08 (Table 4). Donato et al. (2006a) did not observe stable correlations for the relation bunch mass and stem length during the production cycles for the studied genotypes. Soares (2013) states that the bunch mass does not depend of the stem length. Thus, it can be suggested that it is not a consistent and reliable variable to compose a harvest prediction equation, although it is an easily measured and non-destructive variable.

Stem diameter is an easily measurable variable in the field, with significant, positive and relatively high correlation, 0.69 and 0.68 (Table 4), respectively, for 'Dwarf Prata' and 'BRS Platina'. Similar results were obtained by Soares (2013), with the Tropical cultivar which denotes a general pattern of straight variation of bunch mass with the stem diameter, an expected result. This happens because bunches are composed of hands (fruits) and stem (rachis), and the bigger bunches have longer rachises (Jaramillo, 1982), although the percentual participation of the rachis in the bunch mass decreases with the increase on its mass. Such behavior was proved by Jaramillo (1982) for Cavendish type cultivars and Azevedo et al. (2010) for Prata type cultivars, with tall stature.

The bunch mass shows large variation among bunches with the same number of hands and usually increases with the number of hands. However, it may change this variation pattern in function of variations in mass, diameter and length of fruits, number of fruits per bunch and fluctuations in the mass of the rachis (Jaramillo, 1982). Donato et al. (2008) found, for 'Tropical' bananas, the same average bunch mass, 14.32 and $14.85 \mathrm{~kg}$, for the first and second cycle, respectively, despite the number of hands have increased from 5 to 7 . The absence of increments between cycles, for the bunch mass, was due to the decrease observed in mass, length and diameter of the fruit from 158.07 to $103.74 \mathrm{~g}, 15.88$ to $14.39 \mathrm{~cm}$, and 40,77 to $34.13 \mathrm{~mm}$, respectively.

However, in this study, the correlations between bunch mass and number of hands were significant and positive, with the highest correlation coefficient associated to the genitor 'Dwarf Prata' (0.70). The hybrid BRS Platina showed a lower correlation coefficient $(0.60)$ for the same variables (Table 4). According to Donato et al. (2006a), for the evaluated genotypes, this association was stable, positive and with a high magnitude. Moreover, it is noteworthy that the variable number of bunches has a discrete quantitative nature, being easy to apply in practice. It can be obtained at the flowering stage and about 120 to 150 days before harvesting the 'Dwarf Prata' and 'BRS Platina' bunches. That, associated to the age marking of the bunch technique as a criterion for harvesting point (Lichtemberg et al., 2008), allows predicting harvest time and yield with greater accuracy, which qualifies its use in a harvest prediction model. 
Table 5. Phenotypic correlation coefficients between bunch and hands masses and individual masses from the first to the tenth hand in Prata type bananas, 'Dwarf Prata' and 'BRS Platina'.

\begin{tabular}{lcccc}
\hline \multirow{2}{*}{ Bunch yield characteristics } & \multicolumn{2}{c}{ Genotypes } & \multicolumn{2}{c}{ Genotypes } \\
\cline { 2 - 5 } & \multicolumn{2}{c}{ Mass of bunch } & \multicolumn{2}{c}{ Mass of hands } \\
\cline { 2 - 5 } & Dwarf Prata & BRS Platina & Dwarf Prata & BRS Platina \\
\hline Mass of the first hand & $0.61^{\star \star}$ & $0.60^{\star \star}$ & $0.62^{\star \star}$ & $0.57^{\star \star}$ \\
Mass of the second hand & $0.62^{\star \star}$ & $0.67^{\star \star}$ & $0.63^{\star \star}$ & $0.65^{\star \star}$ \\
Mass of the third hand & $0.86^{\star \star}$ & $0.80^{\star \star}$ & $0.87^{\star \star}$ & $0.80^{\star \star}$ \\
Mass of the fourth hand & $0.85^{\star \star}$ & $0.85^{\star \star}$ & $0.86^{\star \star}$ & $0.85^{\star \star}$ \\
Mass of the fifth hand & $0.88^{\star \star}$ & $0.83^{\star \star}$ & $0.89^{\star \star}$ & $0.82^{\star \star}$ \\
Mass of the sixth hand & $0.84^{\star \star}$ & $0.79^{\star \star}$ & $0.86^{\star \star}$ & $0.78^{\star \star}$ \\
Mass of the seventh hand & $0.82^{\star \star}$ & $0.81^{\star \star}$ & $0.84^{\star \star}$ & $0.80^{\star \star}$ \\
Mass of the eighth hand & $0.85^{\star \star}$ & $0.62^{\star \star}$ & $0.87^{\star \star}$ & $0.59^{\star \star}$ \\
Mass of the ninth hand & $0.83^{\star \star}$ & $0.69^{\star \star}$ & $0.83^{\star \star}$ & $0.70^{\star \star}$ \\
Mass of the tenth hand & $0.83^{\star \star}$ & $0.64^{\star}$ & $0.85^{\star \star}$ & $0.67^{\star}$ \\
\hline
\end{tabular}

${ }^{* *}$ and ${ }^{\text {ns }}$ : significant at $1 \%$ level of significance and non-significant, respectively.

As well as the number of bunches, the number of fruits can be measured in the field. The correlation between bunch mass and number of fruits was statistically significant, positive and with appropriate magnitude. The estimate of 0.74 for both genotypes, Dwarf Prata and BRS Platina (Table 4), was higher, also, for the two genotypes than the correlation between bunch mass and number of hands. Lima Neto et al. (2003) and Soares (2013) obtained positive and significant correlation estimates for most of the studied genotypes. Donato et al. (2006a) found significant positive correlations, with values close to the present study, for 'BRS Platina' and positive and non-significant for 'Dwarf Prata'. However, these authors reported negative and significant correlation estimates between bunch mass and number of fruit for Calipso and Preciosa genotypes, and positive and significant between bunch mass and average fruit mass, indicating that the bunches with higher mass can have a lower number of fruits, yet with larger fruits. In this sense, the variable number of fruits anticipates the quantitative characteristics of the bunch at the harvest time, being, therefore, highly reliable for harvest estimate, as well as being easy to measure in field conditions.

Similarly, correlation between bunch mass and fruits mass were found significant values, positive, only with higher magnitudes for 'Dwarf Prata' (0.86) and for 'BRS Platina' (0.89) (Table 4). However, the high values for this correlation have a difficult application in a harvest prediction equation for practical reasons, because it is a destructive and hard to measure variable. Thus, it would not be an interesting variable to compose a harvest prediction equation.

Significant and positive correlations were found between the bunch mass and the hands mass, from the first to the tenth hand, for both evaluated genotypes (Table 5). The highest correlation coefficients, both for the bunch mass and for the hands mass, were observed in association with the mass of the fifth hand for the 'Dwarf Prata', and with the mass of the fourth hand for 'BRS Platina'. For that reason, the characteristics of these bunches have the potential to compose the harvest prediction models.

So, considering the analysis of Table 5 , it can be suggested that the fifth and fourth hands, respectively, for 'Dwarf Prata' and 'BRS Platina', show higher reliability to compose the harvest prediction equation, both to estimate bunch mass, and the hands mass. However, these are considered destructible samples, since the hand must be extracted to obtain the mass.

Aiming to minimize the losses when sampling the variables due to removal of the hands, a correlation study was carried out with the unitary descriptors of the central fruit of the external and internal rows, due to the lower impact of removing those to measure the bunch. For that, evaluations were made of the number of fruits per hand and the length, diameter and mass of the fruits, both from the external and internal rows of the hands. For such measurements, the hands from the first to the tenth position were used. The correlations between bunch mass and the mass of the fruit from the external row, from the first to the tenth hand, were significant and positive, and with higher values when compared to the other descriptors (Table 6).

Correlations between bunch mass and the masses of the fruits from the external row of the ninth and tenth hands (0.80) for the 'Dwarf Prata', and the mass of the fruits from the external row of the eighth (0.73) and ninth (0.79) hands for the 'BRS Platina', have the higher correlation coefficient values (Table 6). However, these hands are not recommended to compose the harvest prediction model due to the limitation of the number of hands in the bunch, as bunches of these genotypes in field conditions usually have 7 to 13 hands. This way, the prediction equation would be limited to predicting 
Table 6. Phenotypic correlation coefficients between bunch and hands masses and the individual masses of the central fruits from the external row from the first to the tenth hand in Prata type bananas, 'Dwarf Prata' and 'BRS Platina'.

\begin{tabular}{|c|c|c|c|c|}
\hline \multirow{3}{*}{ Hands yield characteristics } & \multirow{2}{*}{\multicolumn{2}{|c|}{$\begin{array}{l}\text { Genotypes } \\
\text { Bunch mass }\end{array}$}} & \multirow{2}{*}{\multicolumn{2}{|c|}{$\begin{array}{c}\text { Genotypes } \\
\text { Hands mass }\end{array}$}} \\
\hline & & & & \\
\hline & Dwarf Prata & BRS Platina & Dwarf Prata & BRS Platina \\
\hline $\begin{array}{l}\text { Mass of the central fruit on the external row of } \\
\text { the first hand }\end{array}$ & $0.73^{\star \star}$ & $0.64^{\star *}$ & $0.75^{\star \star}$ & $0.63^{\star \star}$ \\
\hline $\begin{array}{l}\text { Mass of the central fruit on the external row of } \\
\text { the second hand }\end{array}$ & $0.67^{\star \star}$ & $0.60^{\star \star}$ & $0.70^{\star \star}$ & $0.59 * \star$ \\
\hline $\begin{array}{l}\text { Mass of the central fruit on the external row of } \\
\text { the third hand }\end{array}$ & $0.67^{\star \star}$ & $0.56^{\star *}$ & $0.70^{\star \star}$ & $0.55^{\star \star}$ \\
\hline $\begin{array}{l}\text { Mass of the central fruit on the external row of } \\
\text { the fourth hand }\end{array}$ & $0.73^{\star \star}$ & $0.61^{\star \star}$ & $0.75^{\star \star}$ & $0.61^{\star *}$ \\
\hline $\begin{array}{l}\text { Mass of the central fruit on the external row of } \\
\text { the fifth hand }\end{array}$ & $0.70^{\star \star}$ & $0.67^{\star \star}$ & $0.71^{\star *}$ & $0.66^{\star \star}$ \\
\hline $\begin{array}{l}\text { Mass of the central fruit on the external row of } \\
\text { the sixth hand }\end{array}$ & $0.70 * \star$ & $0.66^{\star \star}$ & $0.71^{\star \star}$ & $0.65^{\star \star}$ \\
\hline $\begin{array}{l}\text { Mass of the central fruit on the external row of } \\
\text { the seventh hand }\end{array}$ & $0.68^{\star \star}$ & $0.65^{\star \star}$ & $0.70^{\star \star}$ & $0.64^{\star \star}$ \\
\hline $\begin{array}{l}\text { Mass of the central fruit on the external row of } \\
\text { the eighth hand }\end{array}$ & $0.71^{\star *}$ & $0.73^{\star \star}$ & $0.73^{\star \star}$ & $0.73^{\star \star}$ \\
\hline $\begin{array}{l}\text { Mass of the central fruit on the external row of } \\
\text { the ninth hand }\end{array}$ & $0.83^{\star \star}$ & $0.79^{\star \star}$ & $0.83^{\star \star}$ & $0.80^{\star \star}$ \\
\hline $\begin{array}{l}\text { Mass of the central fruit on the external row of } \\
\text { the tenth hand }\end{array}$ & $0.80^{\star *}$ & $0.40^{\mathrm{ns}}$ & $0.82^{\star \star}$ & $0.38^{\mathrm{ns}}$ \\
\hline
\end{tabular}

${ }^{\star *}$ and $^{\text {ns }}$ : Significant at $1 \%$ level of significance and non-significant, respectively.

bunches with more than 8 hands for the 'BRS Platina' and more than 9 hands for 'Dwarf Prata'. However, for those considerations, it can be suggested to include in the prediction model the masses of the fruit from the external row of the fourth (0.73) and fifth (0.67) hands, for 'Dwarf Prata' and 'BRS Platina', respectively (Table 6). An additional reason is the fact that the masses of the fourth and fifth hands show higher correlation coefficients with the masses of bunch and hands, which directed to estimates of models involving unitary characteristics of these hands.

Similar correlations, in magnitude and significance, were also found between hands mass and mass of the fruit on the external row, from the first to the tenth hand (Table 6). In this case, they were also considered the higher correlation coefficient values, coupled with the practical aspects discussed, as the number of hands normally found for the evaluated genotypes. Thus, the association between hands mass and mass of the fruit on the external row of the fourth (0.75) and fifth (0.66) hands, for 'Dwarf Prata' and 'BRS Platina' (Table 6), respectively, show higher application to compose the harvest prediction model, based on yield characteristics.

\section{Conclusion}

Higher correlation coefficient between yield and vegetative characteristics, for 'Dwarf Prata' and 'BRS Platina', was obtained for the pseudostem perimeter at ground level, which indicates higher potential to compose the harvest estimate. The correlations between bunch and hands masses with the yield characteristics, for both genotypes, presented higher prediction potential for number of hands and fruits. Adequate correlation estimates are associated to the fourth and fifth hands, for the 'Dwarf Prata' and 'BRS Platina', respectively, using the mass of the fruit from the external row.

\section{Conflict of Interests}

The authors have not declared any conflict of interests.

\section{ACKNOWLEDGEMENTS}

The authors would like to thank FAPEMIG (Minas Gerais State Foundation for Research Development), CAPES (Coordination for Improvement of Higher Level Personnel) and CNPq (National Counsel of Technological and Scientific Development) for the financial support.

\section{REFERENCES}

Arantes AM, Donato SLR, Silva SO (2010). Relação entre 
características morfológicas e componentes de produção em plátanos. Pesq. Agropec. Bras. 45:224227.http://dx.doi.org/10.1590/S0100-204X2010000200015

Azevedo VF, Donato SLR, Arantes AM, Maia VM, Silva SO (2010). Avaliação de bananeiras tipo prata, de porte alto, no semiárido. Ciênc. agrotec. 34:1372-1380

Donato SLR, Silva SO, Lucca Filho OA, Lima MB, Domingues H, Alves JS (2006a). Correlações entre caracteres da planta e do cacho em bananeira (Musa spp). Ciênc. Agrotec. 30:21-30.http://dx.doi.org/10.1590/S1413-70542006000100003

Donato SLR, Siqueira DL, Silva SO, Cecon PR, Silva JA, Salomão LCC (2008). Estimativas de tamanho de parcelas para avaliação de descritores fenotípicos em bananeira. Pesq. Agropec. Bras. 43:957969.http://dx.doi.org/10.1590/S0100-204X2008000800003

Donato SLR, Arantes AM, Silva SO, Cordeiro ZJM (2009). Comportamento fitotécnico da bananeira 'Prata-Anã' e de seus híbridos. Pesq. Agropec. Bras. 44:16081615.http://dx.doi.org/10.1590/S0100-204X2009001200007

FAO-FOOD AND AGRICULTURE ORGANIZATION. Banana. 2012. Available in: <http://faostat.fao.org/site/567/DesktopDefault.aspx?PagelD=567\#an cor>. Access in: feb 27, 2014. IPGRI- International Plant Genetic Resources Institute. Descriptors for banana (Musa spp.). Rome: IPGRI, 1996, P. 55.

Hernández MS, Martínez O, Fernández-Trujillo JP (2007). Behavior of arazá (Eugenia stipitata Mc Vaugh) fruit quality traits during growth, development and ripening. Sci. Hortic-Amsterdam. 111:220227.http://dx.doi.org/10.1016/j.scienta.2006.10.029

Jaramillo RC (1982). Las principales características morfológicas Del fruto de banano, variedade Cavendish Gigante (Musa AAA) em Costa Rica. Upeb-Impretex. P. 42.

Lima Neto FP, Silva SO, Flores JCO, Jesus ON, Paiva LE (2003). Relação entre caracteres de rendimento e desenvolvimento em genótipos de bananeira. Magistra. 15:275-281.

Ledo AS, Silva Júnior JF, Lédo CAS, Silva SO (2008). Avaliação de genótipos de bananeira na região do Baixo São Francisco, Sergipe. Rev. Bras. Frutic. 30:691-695.http://dx.doi.org/10.1590/S010029452008000300022

Lichtemberg LA, Vilas Boas EVB, Dias MSC (2008). Colheita e póscolheita da banana. Informe agropecuário. 29:92-110.

Maia E, Siqueira DL, Silva FF, Peternelli LA, Salomão LCC(2009). Método de comparação de modelos de regressão não lineares em bananeiras. Cienc. 39:13801386.http://dx.doi.org/10.1590/S0103-84782009000500012

Marques PRR, Donato SLR, Pereira MCT, Coelho EF, Arantes AM (2011). Características agronômicas de bananeira tipo Prata sob diferentes sistemas de irrigação. Pesq. Agropec. Bras. 46:852859.http://dx.doi.org/10.1590/S0100-204X2011000800010

Oliveira TK, Lessa LS, Silva SO, Oliveira JP (2008). Características agronômicas de genótipos de bananeira em três ciclos de produção em Rio Branco, AC. Pesq. Agropec. Bras. 43:10031010.http://dx.doi.org/10.1590/S0100-204X2008000800008

Robinson JC, Galán Saúco V (2010). Bananas and plantains. 2nd ed. Oxford: CAB International. 311p. (Crop production science in horticulturae $\quad$ series, $\quad P . \quad 19$. http://dx.doi.org/10.1079/9781845936587.0000

Rodrigues MGV, Dias MSC, Pacheco DD (2009). Influência de diferentes níveis de desfolha na produção e qualidade dos frutos da bananeira 'Prata Anã'. Rev. Bras. Frutic. 31:755-762. http://dx.doi.org/10.1590/S0100-29452009000300019

Rodrigues MGV, Donato SLR, Rodrigues FE (2011). Panorama del Sector bananero en el Norte de Minas Gerais, Brasil. Boletín Musalac. Costa Rica: Red de Investigación y Desarrollo de Banano y Plátano para América Latina y el Caribe. 2:3-5.

Scarpari MS, Beauclair EGF (2009). Physiological model to estimate the maturity of sugarcane. Sci. Agric. (Piracicaba, Braz.). 66:622-628.

Soares JDR, Pasqual M, Rodrigues FA, Lacerda WS, Donato SLR, Silva SO, Paixão CA (2012). Correlation between morphological characters and estimated bunch weight of the Tropical banana cultivar. Afr. J. Biotechnol. 11:10682-10687.
Silva SO, Flores JCO, Lima Neto FP (2002). Avaliação de cultivares e híbridos de bananeira em quatro ciclos de produção. Pesq. Agropec. Bras. 37:1567-1574. http://dx.doi.org/10.1590/S0100204X2002001100007

Silva SO, Pereira LV, Rodrigues MGV (2008). Bananicultura irrigada: inovações tecnológicas: variedades. Informe Agropecuário. 29:78-83.

Siqueira DL (1984). Variabilidade e correlações de caracteres em clones da bananeira 'Prata'. 68p. Master's dissertation - Escola Superior de Agricultura de Lavras, Lavras.

Soares JDR, Pasqual M, Lacerda WS, Silva SO, Donato SLR (2013). Utilization of artificial neural networks in the prediction of the bunches' weight in banana plants. Sci Hortic-Amsterdam. 155:24-29. http://dx.doi.org/10.1016/j.scienta.2013.01.026

Steel RGD, Torrie JH, Dickey DA (1997) Principles and procedures of statistics: a biometrical approach, McGraw-Hill. P. 666.

Tenkouano R, Ortiz R, Baiyeri KP (2002). Phenotypic correlations in Musa populations in Nigeria. Afr. Crop. Sci. J. 10:121-132.

Vencovsky R, Barriga P (1992). Genética Biométrica no Melhoramento. Ribeirão Preto: SBG. P. 496. PMCid:PMC1004926 